\title{
Rangsangan Titik Akupunktur Nomer 16 Meningkatkan Kadar Hormon Testosteron Mencit Jantan Usia Sembilan Bulan
}

\author{
Tanjung Subrata \\ Bagian Fisiologi Fakultas Kedokteran dan Ilmu Kesehatan Universitas Warmadewa, Denpasar \\ Email: tanjung.subrata@gmail.com
}

\begin{abstract}
Abstrak
Penurunan kadar testosteron pada laki-laki mulai usia pertengahan antara 45-59 tahun dan menyebabkan terjadinya ganguan seperti menurunnya kekuatan otot, meningkatnya lemak visceral, gangguan fungsi seksual seperti libido menurun dan/atau disfungsi ereksi. Akupunktur dengan konsep pengobatan hantaran rangsang dapat digunakan untuk meningkatkan fungsi seksual laki-laki. Pada penelitian ini diteliti pengaruh perangsangan pada titik akupunktur no.16 dan 49 terhadap kadar hormon testosteron pada mencit (Mus musculus) yang telah mengalami proses penuaan. Sebanyak 28 ekor mencit jantan usia 9 bulan dijadikan binatang coba. Binatang coba dibagi menjadi empat kelompok eksperimen secara random. Kelompok 1 diberikan rangsangan pada titik akupunktur no.16, kelompok 2 diberikan rangsangan pada titik akupunktur no.49 dan kelompok 3 diberi rangsangan pada titik akupunktur no.16 dan 49, dan kelompok 4 sebagai kontrol. Perlakuan diberikan selama 10 menit, diulang sebanyak tiga kali per minggu, dan diberikan selama empat minggu. Kadar hormon testosteron diukur dari sampel darah mencit setelah perlakuan selesai. Perbedaan rerata kadar hormon testosterone antar kelompok eksperimen diuji dengan uji Kruskal-Wallis dan Man-Whitney pada tingkat kemaknaan $\mathrm{a}=0,05$. Hasil penelitian menunjukan rerata $( \pm \mathrm{sd})$ kadar hormon testosteron pada kelompok 1, 2, 3, dan 4 adalah 815,0 $( \pm 568,8) \mathrm{ng} / \mathrm{dl}, 229,5( \pm 337,4) \mathrm{ng} / \mathrm{dl}, 538,2( \pm 715,0)$ $\mathrm{ng} / \mathrm{dl}$, dan $50,8( \pm 32,2) \mathrm{ng} / \mathrm{dl}$ secara berurutan. Analisis Mann-Whitney menunjukan bahwa kadar testosteron kelompok eksperimen 1 berbeda dengan kelompok lain dan control $(\mathrm{P}<0,05)$. Sehingga dapat disimpulkan bahwa pemberian rangsangan pada titik akupunktur no.16 meningkatkan kadar hormon testosteron mencit secara signifikan.
\end{abstract}

Kata Kunci: akupunktur, hormon testosteron, mencit tua

\section{Abstract \\ [Stimulation on Acupuncture Point Number 16 Increases Testosterone Hormone Level in Nine-Month-old Male Mice].}

Decreasing level of testosterone in man starts at the age between 45-59 years which causes disorders such as decreased muscle strength, increased visceral fat, sexual dysfunction such as decreased libido and / or erectile dysfunction. Acupuncture with excitatory conduction treatment concept can be used to enhance male sexual function. In this study we examined the effect of stimulation of acupuncture points no.16 and 49 on testosterone levels in mice (Mus musculus) who are aging. A total of 28 male mice aged 9 months were used as experimental animals. The experiment animals were divided into four groups randomly. Group 1 was given stimulation of acupuncture pointno.16, group 2 was given stimulation of acupuncture point 49 and group 3 was given stimulation of acupuncture points no.16 and 49, and group 4 as the control group. Treatment was given for 10 minutes, repeated three times per week, for four weeks. Testosterone levels were measured from blood samples of mice after treatment was completed. The mean differences of testosterone levels between experimental groups were tested by Kruskal-Wallis and Man-Whitney at significance level a $=0.05$. The results showed the mean ( \pm sd) of testosterone levels in group 1, 2, 3, and 4 were 815.0 ( \pm 568.8$) \mathrm{ng} / \mathrm{dl}, 229.5$ $( \pm 337.4) \mathrm{ng} / \mathrm{dl}, 538,2( \pm 715,0) \mathrm{ng} / \mathrm{dl}$, and $50.8( \pm 32.2) \mathrm{ng} / \mathrm{dl}$, respectively. Mann-Whitney analysis showed that testosterone level of group 1 was different from those of the other groups and the control $(P<0.05)$. It is concluded that stimulation of acupuncture pointno. 16 increases testosterone levels in mice significantly.

Keywords: acupuncture, testosterone hormone, aging mice 


\section{PENDAHULUAN}

Hormon kelamin pria atau yang lebih dikenal sebagai testosteron adalah hormon yang diproduksi oleh organ testis. ${ }^{[1]}$ Kadar hormon testosteron mengalami penurunan mulai usia pertengahan yaitu antara usia 4559 tahun. Penurunan hormon testosteron yang disertai penurunan fungsi reproduksi adalah merupakan aging process, yang menyebabkan menurunnya massa dan kekuatan otot, libido, dan frekuensi hubungan seksual. ${ }^{[2,3]}$ Penurunan kadar testosteron ini dapat diatasi dengan pemberian Testosterone Replacement Therapy (TRT), yang dalam berbagai uji klinis memberikan hasil yang cukup memuaskan, tapi TRT juga memiliki beberapa kelemahan selain harga yang relatif mahal dan pemberian yang terus menerus juga memiliki kontraindikasi pada kanker prostat. ${ }^{[4,5]}$

Akupunktur adalah suatu metode terapi dengan konsep hantaran rangsangan, yang berasal dari daratan China, dan telah berkembang sekitar 5000 tahun yang lalu. Fenomena hantaran rangsang dari suatu area di tubuh, tidak terlepas dari terjadinya hantaran rangsang pada daerah perlakuan, yang disebut sebagai sinyal transduksi. ${ }^{[6]}$ Terjadinya migrasi isotop teknesium perteknetat (sinar gamma) melalui sinyal tranduksi intraseluler dan timbulnya gambaran cacah yang tinggi pada organ testis ipsilateral dari tempat suntikan pada titik Ki. 3 orang coba. Titik akupunktur Ki3 pada manusia analog dengan titik akupunktur no. 49 pada mencit. Titik akupunktur no. 49 merupakan hantaran rangsangan dari kaki melalui jalur meridian ke testis. ${ }^{[7]}$ Titik akupunktur no. 16 merupakan hantaran rangsangan dari spinal menuju thalamus (spino thalamikus trak.). ${ }^{[8]}$ Adikara membuktikan adanya rangsangan tersebut akan mempengaruhi sekresi hormon-hormon hipothalamus-pituitari. ${ }^{[8]}$

Pada paper ini dibahas efek akupunktur, khusunya perangsangan titik akupunktur no. 16 dan 49 terhadap kadar hormon testosteron pada mencit jantan. Tujuan dari penelitian ini adalah untuk mengetahui pengaruh perangsangan titik akupunktur no 16 dan 49 terhadap peningkatan kadar testosteron dengan hipotesis yang ingin dibuktikan adalah perangsangan titik akupunktur no. 16 atau no 49 dapat meningkatkan kadar hormon testosteron mencit jantan usia 9 bulan.

\section{METODE}

Penelitian eksperimental dengan rancangan Randomized post test only control group design dilakukan pada 28 ekor mencit (Mus musculus) jantan usia 9 bulan dengan berat badan antara 35-40 gram dan memiliki panjang badan mulai dari pangkal ekor sampai ujung hidung antara $8-10 \mathrm{~cm} .{ }^{[9]}$ Mencit pada usia tersebut telah mengalami proses penuaan. ${ }^{[10]}$ Pada penelitian ini, binatang coba dibagi menjadi 4 kelompok, yaitu 3 kelompok perlakuan dan 1 kelompok kontrol. Kelompok 1 (P1) diberikan rangsangan akupunktur pada titik akupunktur no.16, kelompok 2 (P2) diberikan rangsangan akupunktur pada titik akupunktur no.49, kelompok 3 (P3) diberikan rangsangan akupunktur pada titik akupunktur no.16 dan no.49, dan kelompok 4 (P4) adalah kontrol yang diberikan rangsangan akupunktur pada jarak $1 \mathrm{~cm}$ sebelah lateral dari titik akupunktur no. 16.

Perlakuan perangsangan akupunktur pada titik akupunktur 16 dilakukan dengan cara menusukan jarum akupungkur pada titik akupunktur di garis tengah punggung antara vertebra lumbal IV dan $\mathrm{V}$ dengan kedalaman 2-3 $\mathrm{mm}$. Perangsangan titik akupunktur no. 49 dilakukan dengan menusukan jarum akupunktur ke dalam musculus flexor digitalis longus pedis dan tendon achiles dengan ke dalaman 2-3 mm, yang merupakan titik akupunktur kaki belakang yang terletak pada tepi kaudal maleolus medialis. ${ }^{[1,12]}$ Perangsangan akupunktur dilakukan dengan prosedur: mencit diletakkan pada papan dan difiksasi dengan kawat jaring, dilakukan persiapan daerah uji dengan pembersihan bulu, disinfeksi dengan Etanol 70\%, kemudian ditusukan jarum akupunktur $38 \mathrm{G}$ sedalam 2 $-3 \mathrm{~mm}$ pada titik akupunktur sesuai dengan perlakuan. Perangsangan dilakukan selama 10 menit dan dilakukan sebanyak tiga kali 
dalam seminggu.

Kadar hormon testosteron diukur dari sampel darah vena yang diambil dari ekor mencit setelah perlakuan selesai. Kadar hormon testoteron diperiksa dengan teknik radioimmunoassay yang dilakukan di laboratorium Kebidanan Fakultas Kedokteran Hewan Universitas Airlangga Surabaya.

Data kadar hormone testosteron dari setiap kelompok eksperiemen tidak berdistribusi normal (uji KS: $\mathrm{P}<0,05$ ) dan tidak homogen (levene's test: $p<0,05$ ), maka perbedaan rerata kadar hormon tertosteron diuji dengan uji Kruskal-Wallis dan dilanjutkan dengan uji Mann-Whitney pada tingkat kemaknaan $\mathrm{a}=0,05$.

\section{HASIL}

Dari 28 mencit yang diteliti, sebanyak $24(85,7 \%)$ dapat menyelesaikan penelitian dan 1 ekor dari masing-masing kelompok mati sebelum penelitian selesai.

Tabel 1. Perbedaan kadar hormon testosteron antar kelompok eksperimen

\begin{tabular}{cccc}
\hline $\begin{array}{c}\text { Kelompok } \\
\text { Perlakuan }\end{array}$ & $\mathrm{n}$ & Rerata $( \pm$ sd $)$ & $\begin{array}{c}\text { Nilai P (Kruskal } \\
\text {-Wallis })\end{array}$ \\
\hline P1 & 6 & $815,0( \pm 568,8)$ & 0,041 \\
P2 & 6 & $229,5( \pm 337,8)$ & \\
P3 & 6 & $538,2( \pm 715,0)$ & \\
P4 & 6 & $50,8( \pm 32,2)$ & \\
\hline
\end{tabular}

Ket: P1: titik akupunktur no.16

P2: titik akupunktur no.49

P3: titik akupunktur no. 16 dan 49

P4: kontrol

Hasil analisis perbedaan rerata kadar hormon testosteron antar kelompok eksperimen seperti yang disajikan pada Tabel 1, menunjukan bahwa paling sedikit ada satau kelompok eksperimen yang memiliki kadar hormon testosteron yang berbeda dengan kelompok eksperimen lainnya $(p<0,05)$. Dari hasil analisis perbedaan antar kelompok dengan uji Mann -Whitney didapatkan bahwa perangsangan akupunktur pada titik akupunktur no.16 dan 49 memberikan efek peningkatan kadar hormon testosteron, akan tetapi hanya perangsangan pada titik akupunktur no. 16 yang memberikan efek peningkatan bermakna, seperti yang disajikan pada Tabel 2.

Tabel 2. Analisis perbedaan kadar testosteron antar kelompok eksperimen

\begin{tabular}{ccc}
\hline $\begin{array}{c}\text { Kelompok } \\
\text { yang } \\
\text { dibandingkan }\end{array}$ & $\begin{array}{c}\text { Beda rerata } \\
\text { (ng/d) }\end{array}$ & $\begin{array}{c}\text { Nilai p } \\
\text { (Mann- } \\
\text { Whitney) }\end{array}$ \\
\hline P1-P4 & 746,2 & 0,016 \\
P2-P4 & 178,7 & 0,150 \\
P3-P4 & 487,4 & 0,065 \\
P1-P2 & 585,5 & 0,065 \\
P1-P3 & 276,8 & 0,423 \\
P2-P3 & $-308,7$ & 0,337 \\
\hline
\end{tabular}

Hasil uji statistik dengan uji Mann Whitney menunjukan, bahwa pemberian rangsangan titik akupunktur no. 16 (P1) pada mencit jantan usia sembilan bulan selama 4 minggu, dapat meningkatkan kadar hormon testosteron mencit jika dibandingkan dengan kontrol secara bermakna $(p<0,05)$. Sedangkan rangsangan titik akupunktur no. 49 (P2) dan titik akupunktur no.16 dan no.49 (P3), pada mencit jantan usia sembilan bulan selama 4 minggu terdapat peningkatan rata-rata kadar hormon testosteron mencit jika dibandingkan dengan kontrol (P4), tapi tidak signifikan $(p>0,05)$. Tidak terdapat perbedaan yang signifikan antara kelompok perlakuan $\mathrm{P} 1$ dengan $\mathrm{P} 2$, perlakuan $\mathrm{P} 1$ dengan P3, dan kelompok perlakuan P2 dengan P3.

\section{DISKUSI}

Testosteron adalah hormon kelamin pria yang diproduksi oleh organ testis. Produksi testosteron oleh testis dipengaruhi oleh Luteinizing Hormone (LH) dan Follicle Stimulating Hormone (FSH) yang dihasilkan oleh kelenjar Hipofise. LH mempengaruhi sel Leydig pada testis untuk memproduksi testosterone. ${ }^{[1]}$ Kelenjar Hipofise anterior dipengaruhi oleh hipothalamus, di mana low frequency pulse akan merangsang pelepasan FSH. 
Sebaliknya, high frequency pulse akan merangsang pelepasan $\mathrm{LH}^{[13]}$. Kadar FSH dan LH selalu pada critical range karena adanya feed back mechanism. ${ }^{[1]}$

Penurunan hormon testosteron pada pria lanjut usia (lansia) dikarenakan adanya gangguan fungsi dan penurunan aktivitas sel Leydig pada testis, gangguan pada feed back mechanism pada HipothalamicPituitary-Testis axis, gangguan irama circadian, dan menurunnya bioavailability dari hormon seks. Rata-rata penurunan hormon testosteron pada lanjut usia adalah $1 \%-2 \%$ setiap tahunnya. ${ }^{[3]}$

Titik akupunktur merupakan kumpulan sel yang berbeda aktivitas listriknya dibanding dengan sel di luar titik akupunktur. Titik akupunktur mempunyai tegangan listriknya tinggi dengan hambatan rendah dan memiliki aktifitas migrasi ITP (Isotop Teknesium Perteknetat) yang aktif. [14]

Secara konseptual, akupunktur merupakan suatu cara pengobatan yang memanfaatkan rangsangan pada titik-titik akupunktur sehingga mempengaruhi aliran bioenergi dalam tubuh. ${ }^{[15]}$ Ada empat cara kerja rangsangan titik-titik akupunktur dalam mempengaruhi keseimbangan homeostasis tubuh dapat dijelaskan dengan empat cara yaitu: melalui reaksi inflamasi local, reflek somato visceral, transmisi neural melalui jalur neuro akupunktur, dan transmisi interseluler melalui jalur meridian. ${ }^{[8]}$

Rangsangan pada titik akupunktur akan menginisiasi proses tranduksi dengan mengubah potensial membran ujung sel saraf dan menghasilkan potensial aksi yang kemudian diteruskan ke sistem saraf pusat. Hantaran rangsang tersebut diteruskan ke sentral melalui tractus ascenderen seperti tractus spinothalamicus, spinoreticularis, dan spinomesencephalicus. ${ }^{[16]}$ Rangsangan akupunktur tersebut akan menimbulkan efek langsung pada sistem parakrin dan autokrin dari steroidogenesis dengan menstimulasi produksi dan pelepasan epineprin, norepineprin (NE), serotonin (5$\mathrm{HT}$ ), gamma amino butyric acid (GABA), growth factors, $\mathrm{LH}$ dan $\mathrm{FSH}^{[13,17]}$
Peningkatan kadar LH akan menimbulkan rangsangan pada sel Leydig testis untuk memproduksi hormon testosteron. ${ }^{[1]}$

Pada penelitian yang menggunakan isotop teknesium perteknetat yang disuntikkan pada titik akupunktur mempunyai gambaran migrasi yang spesifik dibanding dengan jaringan di luar titik akupunktur, pada sinyal transduksi ternyata tidak hanya mengalirkan elektron tapi juga materi selular yang dilabel dengan isotop teknesium perteknetat (ITP). Terjadinya migrasi isotop teknesium perteknetat (sinar gamma) tidak melalui pembuluh darah maupun kelenjar getah bening tetapi melalui sinyal tranduksi intraseluler dan timbul gambaran cacah yang tinggi pada organ testis ipsilateral dari tempat suntikan pada titik Ki. 3 orang coba. Rangsangan pada lokasi titik akupunktur sebagai sekelompok sel aktif listrik, akan menimbulkan aktivitas yang khusus bagi kumpulan sel tersebut berupa depolarisasi ion, stimulasi rRNA, aktivasi mRNA dan proses sintesa protein berlangsung, kemudian terjadi mekanisme komunikasi antar sel melalui sistim transformasi dan informasi dengan C-AMP atau dengan transfer desmosom melalui jembatan antar sel sehingga akan meningkatkan respon selular pada target organ yaitu testis. ${ }^{[15]}$ Titik akupunktur Ki. 3 pada manusia analog dengan titik akupunktur no. 49 pada mencit. ${ }^{[11,12]}$

Hasil beberapa penelitian sebelumnya juga memberikan hasil yang serupa seperti yang dilakukan Adikara ${ }^{[8]}$ dan Rachmawati ${ }^{18]}$ yang menggunakan hewan coba kelinci jantan usia 3 bulan dengan perlakuan rangsangan pada titik akupunktur no 16 yang menghasilkan peningkatan kadar hormon testosteron.

Adapun kelemahan penelitian ini adalah pada penusukan titik akupunktur no.49 (P2) di daerah kaki mencit, mencitmencit tersebut cenderung lebih iritatif dan meronta-ronta selama proses penusukan dibandingkan dengan penusukan pada titik akupunktur no.16 (P1) di daerah punggung. Gerakan-gerakan mencit tersebut mengakibatkan terjadinya pergeseran tusukan jarum akupunktur dari titik 
akupunktur yang seharusnya, dan akibat pergeseran tersebut akan mengurangi efektifitas dari rangsangan akupunktur. Selain faktor tersebut diatas, faktor stress selama perlakuan penusukan jarum pada mencit dapat mempengaruhi kadar hormon testosteron mencit, di mana stress akan merangsang pelepasan hormon kortisol yang berakibat negatif pada kadar hormon testosteron.

Dari hasil penelitian di atas dapat dipertimbangkan penggunaan terapi akupunktur, terutama titik akupunktur no.16 pada manusia, baik sebagai terapi utama ataupun sebagai terapi komplemen dalam mengatasi gangguan-gangguan fisik yang dikarenakan penurunan kadar hormon testosteron, sebagai akibat proses penuaan atau aging process, dengan biaya yang relatif terjangkau dan efek samping yang minimal.

\section{KESIMPULAN}

Dari penelitian ini dapat disimpulkan bahwa pemberian perangsangan akupunktur pada titik akupunktur no.16 selama 10 menit, yang diberikan sebanyak 3 kali seminggu selama 4 minggu, dapat meningkatkan kadar hormon testosteron pada mencit jantan usia 9 bulan dengan peningkatan yang signifikan. Sebaliknya, perangsangan akupunktur yang diberikan pada titik akupunktur no. 49 dengan dosis yang sama, memberikan peningktan yang tidak sigifikan.

\section{UCAPAN TERIMA KASIH}

Penulis menyampaikan ucapan terima kasih kepada semua pihak yang telah membantu dalam pelaksanaan penelitian ini. Secara khusus penulis menyampaikan ucapan terima kasih kepada Prof. Dr. dr. J. Alex Pangkahila, M.Sc., Sp.And., Dr. Koosnadi Saputra, MD., dan Prof. drh. Laba Mahaputra atas kontribusinya selama penelitian dan penulisan artikel ini.

\section{DAFTAR PUSTAKA}

1. Daryl K.G., 1992. Hormon kelamin. In: Harper's Review of Biochemistry, Martin D.W. et all. EGC Penerbit
Buku Kedokteran. Hal. 634-647.

2. Dotson A., 2003. Methods of Testosterone Supplementation for Man and Women. Men's Health Abstracts, December 2003.

3. Kaufman J.M., Vermeulen A., 2005. The Decline of Androgen Levels in Elderly Men and Its Clinical and Therapeutic Implication. Endocrine Reviews 26 (6): 833-876. Copyright (C) 2005 by The Endocrine Society. Published online ahead of print May 18, 2005. Available from: http://edrv.endojournals.org/cgi/ content/short/er/2004 00/3vi. Access: 01/02/2006

4. Arsyad K.M., 2002. Problem pria lansia dari aspek andrologi. Dalam Majalah Andrologi Indonesia, No1, Maret.

5. Pangkahila A., 2002. Disfungsi seksual pada pria andropause. Dalam Buku Acara dan Kumpulan Abstrak, Pertemuan Ilmiah Tahunan XIV Perkumpulan Andrologi Indonesia 1819 Juli dan Kongres Nasional I Asosiasi Seksologi Indonesia 20-21 Juli.

6. Saputra K., 1994. Penelitian Ilmiah Akupunktur Untuk Menunjang Konsep Bio Energi dalam Pengembangan Teknologi Kedokteran. Majalah Kedokteran Indonesia. 44: 45-50.

7. Saputra K., 1992. Acupoints Scintigraphy. Tracing Meridian Acupuncture Corresponding Organ by Radionucleide Technique. Bali. AAR VII, September.

8. Saputra K., Idayanti A., Budiyanto D., Prihatin, 2000. Penelitian Faal Akupunktur. Dalam Akupunktur dalam Penendekatan Ilmu Kedokteran. Airlangga Univercity Press. Surabaya.

9. Arnitage P., Berry G., Matthews J.N.S., 2002. Statistical Methods in Medical Research. Fourth Edition. Massachusetts. Blackwell Publishing Company. 
10. Smith J.B., Mangkoewidjojo S., 1988. Pemeliharaan, Pembiakan dan Penggunaan Hewan Percobaan di Daerah Tropis. Jakarta. UI Press: 84110.

11. Chuan Y., 1987. Origin and Development of The Traditional Chinese Veterinary Acupucture and Its Therapeutic Effect. International Conference on Veterinary Acupuncture. Beijing-China. Beijing Agriculture University. May: 15-18.

12. Anonymous, 1975. Hand book on Chinese veterinary David CC. and WC. Dorothy. The principle of Chinese acupucture medicine life science medical laboratory. Hongkong.

13. Lovejoy D.A., 2005. Reproduction. In: Neuroendocrinology An Integrated Approach. London. John Wiley \& Sons, Ltd.

14. Saputra K., 1997. Titik Akupunktur sebagai Kumpulan Sel Aktif Listrik. Meridian 4: 80-87.
15. Saputra K., 1999. Profil Tranduksi Rangsangan Titik Akupunktur Oryctolangus Cuniclus. Disertasi. Program Pasca Sarjana Universitas Airlangga. Surabaya.

16. Sudirman S., 2005. Neuro Fisiologi Nyeri. Dalam Penanganan Nyeri dengan Neuro Akupunktur. LP3APuslitbang Yantekkes Depkes RI. Surabaya.

17. Jen H.I., Wing W.C., Leang S.W., 2001. Acupucnture for Reproductive Disorder. In: Veterinary Acupuncture Ancient Art to Modern Medicine, Allen M. Schoen. Second Edition. London. Mosby.

18. Rachmawati, N. 1993. Pengaruh tindakan akupunktur terhadap perubahan kadar hormon testosteron kelinci (Orytolagus cuniculus) jantan. [Skripsi]. Surabaya Universitas Airlanga. Fakultas Kedokteran Hewan. 